American Journal of Agricultural and Biological Sciences 5 (3): 370-375, 2010

ISSN 1557-4989

(C) 2010 Science Publications

\title{
Effect of Dietary Inositol on Growth, Feed Utilization and Blood Biochemical Parameters for Juvenile Barramundi (Lates calcarifer Bloch)
}

\author{
Shi-Qiang Diao, Zhong Huang, Shui-Sheng Chen, Jin Niu, \\ Zhuo-Jia Li, Xian Ding and Hei-Zhao Lin \\ South China Sea Fisheries Research Institute of CAFS, \\ 231 Xingang Road Western, Guangzhou 510300, PR, China
}

\begin{abstract}
Problem statement: The utilization of inositol was detected for growth performance and erum biochemical parameters of juvenile barramundi (Lates calcarifer). Approach: A 56 day feeding trial was conducted to evaluate the effect of inositol on growth, feed utilization and serum biochemical parameters for juvenile barramundi Lates calcarifer (initial size $5.51 \pm 0.07 \mathrm{~g}$ ). Six experimental fish meal-based isonitrogenous ( $42 \%$ crude protein) and isolipidic (10\% crude lipid) diets containing levels of inositol (350, 364, 458, 507, 720, $1050 \mathrm{mg} \mathrm{kg}^{-1}$ diet) were formulated. Results: Fish fed diet containing inositol $507 \mathrm{mg} \mathrm{kg}^{-1}$ diet had the significantly highest weight gain (WG, \%) among all the groups $(\mathrm{p}<0.05)$ and had significantly lower Feed Conversion Ratio (FCR) than fish fed the diet containing inositol $458 \mathrm{mg} \mathrm{kg}^{-1}$ diet $(\mathrm{p}<0.05)$. Survival and Hepatosomatic Index (HSI) were not significantly affected by graded levels of dietary inositol ( $p>0.05$ ). However, significantly lower Viscerasomatic Index (VSI) was found in fish fed diet without supplemental inositol $(\mathrm{p}<0.05)$. Dietary inositol levels did not affect whole body moisture, crude protein and lipid contents ( $p>0.05$ ). Total protein and triacylglycerol in serum increased with increasing dietary inositol levels up to $507 \mathrm{mg} \mathrm{kg}^{-1}$ diet $(\mathrm{p}<0.05)$. The significantly lowest blood urea nitrogen was found in fish fed dietary inositol $458 \mathrm{mg} \mathrm{kg}^{-1}$ diet among all groups except for $720 \mathrm{mg} \mathrm{kg}^{-1}$ diet. Total Cholesterol (TC) of fish fed dietary inositol $507-1050 \mathrm{mg} \mathrm{kg}^{-1}$ diet was higher than those of fish fed dietary inositol $350-458 \mathrm{mg} \mathrm{kg}^{-1}$ diet. Conclusion: Results of the present investigation demonstrated significant improvement of growth and feed utilization of juvenile barramundi can be achieved by inositol supplementation at $507 \mathrm{mg} \mathrm{kg}^{-1}$ diet.
\end{abstract}

Key words: Lates calcarifer bloch, inositol, growth, blood biochemical index

\section{INTRODUCTION}

Barramundi (Lates calcarifer) is native to the IndoPacific region (Glencross, 2006) and an economically important species in Southeast Asian countries (Tantikittia et al., 2005). It is a carnivorous species which can be reared in marine water, brackish water, or freshwater (Harpaz et al., 2005). Glencross (2006) reviewed barramundi nutrition research included the requirements for most nutrients, energy demand and ingredient utilization. Recent research indicated that lupin protein (Katersky et al., 2009) and defatted soybean protein (Tantikittia et al., 2005) were suitable protein sources for barramundi feeds. Williams et al. (2006) also indicated that a dietary n-3 HUFA was required for rapid growth and efficient feed conversion of juvenile barramundi. In our laboratory, research has focused on determining effects of dietary Bacillus licheniformis (Yuan et al., 2009) and Chinese herbal medicines (Lu et al., 2009) on blood biochemical indices in cultured Lates calarifer.

Inositol is widely distributed in plants and animals (Peres et al., 2004), which is classified as a vitamin-like nutrient (Shiau and Su, 2005) and is an essential dietary ingredient for most aquatic animals (Michael and Koshio, 2008). The requirement of dietary inositol has been reported by Li et al. (2001), Shiau and Su (2005) and Wen et al. (2007) in various aquatic animals. Dietary inositol also affected blood chemistry in fish (Waagbo et al., 1998; Wen et al. 2007). Certain dietary vitamins have been identified as essential for barramundi; however, it is difficult to define the requirement for all essential vitamins because of poor acceptance of a purified diet by barramundi (Glencross, 2006).

The purpose of this study was to evaluate the influence of the dietary levels of inositol on growth performance, feed utilization and serum biochemical parameters in juvenile barramundi.

Corresponding Author: Hei-Zhao Lin, South China Sea Fisheries Research Institute of CAFS, 231 Xingang Road Western, Guangzhou 510300, PR, China 


\section{MATERIALS AND METHODS}

Experimental diets: Diets were formulated to be grossly isonitrogenous (crude protein, 43\%) and isolipidic (crude lipid, 12\%). The experimental diet formulation and proximate are shown in Table 1. Inositol (Sigma) was added to the test diets at a concentration of $0,50,100,200,400$ and $800 \mathrm{~g} \mathrm{~kg}^{-1}$ diet. All ingredients were mechanically mixed, pressure-pelleted using a laboratory pelleting machine through a $2.5 \mathrm{~mm}$ die. The pellets were air-dried at room temperature to a moisture content of about $10 \%$ and stored in a freezer at $-20^{\circ} \mathrm{C}$ until used.

Experimental fish and feeding: The trial was conducted at an experimental station of South China Sea Fisheries Research Institute of CAFS (Sanya, Hainan). Barramundi were obtained from a private commercial hatchery and acclimated to the laboratory conditions for 2 weeks. At the end of the acclimation period, a total of 540 fish (mean initial weight $5.51 \pm 0.07 \mathrm{~g}$ ) were randomly distributed into each of 18 $500 \mathrm{~L}$ cylindrical plastic tanks. Each experimental diet was randomly assigned to triplicate tanks. Tanks were supplied with filtered seawater with a flow rate of approximately $2 \mathrm{~L} \mathrm{~min}^{-1}$ in a flow-through system with aeration. The fish were fed with the respective diet to apparent satiation twice a day at 0800 and $1700 \mathrm{~h}$. During the trial, the water temperature was maintained ant $29.0 \pm 2.0^{\circ} \mathrm{C}$ and salinity was $28 \pm 0.3 \mathrm{~g} \mathrm{~L}^{-1}$. Dissolved oxygen ranged from $5.10-6.93 \mathrm{mg} \mathrm{L}^{-1}$. The experimental units were under a natural light and dark cycle. The experiment lasted for 56 days.

Sampling: At the conclusion of the 8-week period, the fish were deprived for 1 day prior to sampling, then counted and batch weighed to determine survival, Final Body Weight (FBW), Weight Gain (WG), Feed Conversion Ratio (FCR). Five fish from each tank were randomly collected, killed for the determination of the Hepatosomatic Index (HSI) and Viscerasomatic Index (VSI). Blood was taken by puncturing the caudal veins immediately after catching.

Chemical analysis: Crude protein was determined by the Kjeldahl method using a Kjeltec 2200 Auto Distillation Unit (Foss Tecator AB, Switzerland). Crude lipid was determined by the ether-extraction method using a Soxtec Avanti 2050 (Foss Tecator AB, Switzerland). Moisture and ash were determined using the standard methods (AOAC, 1984). The inositol concentration in the diets was determined using an enzymatic assay as described by Ashizawa et al. (2000).

The standard methods on human were used to determinate biochemical parameters (Rehulka, 2000). The serum was collected by centrifuging blood samples at $3000 \mathrm{rpm}$ for $10 \mathrm{~min}$. The biochemical indices of the serum were determined within $24 \mathrm{~h}$ of storage at $4{ }^{\circ} \mathrm{C}$. A Beckman LX20 automatic biochemical analyzer (Harbor Blvd., Fullerton, USA) was used for the determinations. These included Total Protein (TP), Blood Urea Nitrogen (BUN), Total Cholesterol (TC) and Triacylglycerol (TG).

Table 1: Composition and nutrients content of diets $\left(\mathrm{g} \mathrm{kg}^{-1}\right)$

\begin{tabular}{|c|c|c|c|c|c|c|}
\hline Ingredient & Diet1 & Diet 2 & Diet 3 & Diet 4 & Diet 5 & Diet 6 \\
\hline Fish meal & 360.0 & 360.00 & 360.00 & 360.00 & 360.0 & 360.0 \\
\hline Soybean meal & 270.0 & 27.00 & 27.00 & 27.00 & 270.0 & 270.0 \\
\hline Corn & 100.0 & 10.00 & 10.00 & 10.00 & 100.0 & 100.0 \\
\hline Fermented soybean meal & 100.0 & 10.00 & 10.00 & 10.00 & 100.0 & 100.0 \\
\hline Fish oil & 70.0 & 70.00 & 7.00 & 7.00 & 70.0 & 70.0 \\
\hline Vitamin mix (inositol free) & 1.0 & 1.00 & 0.10 & 0.10 & 1.0 & 1.0 \\
\hline Mineral mix & 5.0 & 5.00 & 0.50 & 0.50 & 5.0 & 5.0 \\
\hline Vitamin C stable & 0.5 & 0.50 & 0.05 & 0.05 & 0.5 & 0.5 \\
\hline Choline chloride & 0.5 & 0.50 & 0.05 & 0.05 & 0.5 & 0.5 \\
\hline Starch & 93.0 & 92.95 & 92.90 & 92.80 & 92.6 & 92.2 \\
\hline Inositol & 0.0 & 0.05 & 0.10 & 0.20 & 0.4 & 0.8 \\
\hline \multicolumn{7}{|l|}{ Nutrients content $\left(\mathrm{g} \mathrm{kg}^{-1}\right)$} \\
\hline Moisture & 95.0 & 95.00 & 104.00 & 96.40 & 98.6 & 105.0 \\
\hline Crude protein & 429.0 & 431.00 & 417.00 & 423.00 & 427.0 & 406.0 \\
\hline Crude lipid & 102.0 & 101.00 & 93.40 & 98.20 & 91.7 & 100.0 \\
\hline Ash & 95.0 & 97.00 & 96.00 & 93.00 & 94.0 & 93.0 \\
\hline Inositol $\left(\mathrm{mg} \mathrm{kg}^{-1}\right)$ & 350.0 & 364.00 & 458.00 & 507.00 & 720.0 & 1050.0 \\
\hline
\end{tabular}

${ }^{1}$ : Vitamin mix $\left(\mathrm{g} \mathrm{kg}^{-1}\right)$ : Retinyl acetate 2.5; cholecalciferol 6.25; all-rac-a-tocopheryl acetate 75 ; menadione 2.5; vthiamin 0.25; riboflavin 1.0; Dcalcium pantothenate 5.0; Pyridoxine HCL 0.75g; Cyanocobalamin 2.5; Niacin 2.5; Folic acid 0.25; Biotine 2.5; cellulose 899; ${ }^{2}$ : Mineral mix (g $\mathrm{kg}^{-1}$ ): $\mathrm{KCl} 90 ; \mathrm{KI} 0.04 ; \mathrm{CaHPO}_{4} \cdot 2 \mathrm{H}_{2} \mathrm{O} 500 ; \mathrm{NaCl} 40 ; \mathrm{CuSO} 4 \cdot 5 \mathrm{H}_{2} \mathrm{O} 3.0 ; \mathrm{ZnSO}_{4} \cdot 7 \mathrm{H}_{2} \mathrm{O} 4.0 ; \mathrm{CoSO}_{4} \cdot 7 \mathrm{H}_{2} \mathrm{O} 0.02 ; \mathrm{FeSO}_{4} \cdot 7 \mathrm{H}_{2} \mathrm{O} 20 ; \mathrm{MnSO}_{4} \cdot \mathrm{H}_{2} \mathrm{O} 3.0 ;$ $\mathrm{CaCO}_{3} 215 ; \mathrm{MgSO}_{4} \cdot 7 \mathrm{H}_{2} \mathrm{O} 124 ;$ Cellulose 0.94 
Statistical analysis: The data were subjected to oneway Analysis Of Variance (ANOVA). If significant $(p<0.05)$ differences were found, Duncan's multiple range test was used to rank the groups using the SPSS program Version 13.0 for Windows (SPSS Inc., Michigan Avenue, Chicago, IL, USA).

\section{RESULTS}

Survival and growth parameters: The fish growth performance of fish fed various dietary inositol was shown in Table 2. Weight gain was the significantly highest for barramundi fed the diet containing inositol $507 \mathrm{mg} \mathrm{kg}^{-1}$ diet among all the groups $(\mathrm{p}<0.05)$. FCR of fish fed the diet containing inositol $507 \mathrm{mg} \mathrm{kg}^{-1}$ diet was significantly lower than the fish fed the diet containing inositol $458 \mathrm{mg} \mathrm{kg}^{-1}$ diet; however, no significant difference was found compared to the other groups. Dietary inositol did not significantly affect survival ( $>0.05)$. Hepatosomatic index was not significantly affected by graded levels of dietary inositol ( $>0.05)$. However, significantly lower viscerasomatic index was found in the fish fed diet without supplemental inositol $(\mathrm{p}<0.05)$.
The proximate composition of the fish whole body: The whole-body composition of fish fed diets containing graded levels of inositol is presented in Table 3. The moisture content of the whole body averaged $71.0 \%$; the crude protein and lipid contents averaged 17.5 and $7.0 \%$, respectively. The moisture, crude protein and lipid contents of the fish whole body was not affected by inositol levels ( $p>0.05)$.

Serum biochemical parameters: Serum biochemical parameters for barramundi fed graded levels of inositol are shown in Table 4. Serum Total Protein (TP) increased with increasing dietary inositol levels up to $507 \mathrm{mg} \mathrm{kg}^{-1}$ diet $(\mathrm{p}<0.05)$. Triacylglycerol (TG) also increased with increasing dietary inositol levels up to 507-720 mg kg ${ }^{-1}$ diet $(\mathrm{p}<0.05)$. The lowest Blood Urea Nitrogen (BUN) was found in the fish fed dietary inositol $458 \mathrm{mg} \mathrm{kg}^{-1}$ diet and was also significantly different compared to $350,364,507$ and $1050 \mathrm{mg} \mathrm{kg}^{-1}$ $\operatorname{diet}(\mathrm{p}<0.05)$. Total Cholesterol (TC) of fish fed dietary inositol $507-1050 \mathrm{mg} \mathrm{kg}^{-1}$ diet was higher than those of fish fed dietary inositol $350-458 \mathrm{mg} \mathrm{kg}^{-1}$ diet, but no significant difference was observed ( $\mathrm{p}>0.05)$.

Table 2: Effect of different dietary inositol levels on growth parameters of Lates calcarifer

\begin{tabular}{|c|c|c|c|c|c|c|}
\hline \multirow[b]{2}{*}{ Parameters } & \multicolumn{6}{|c|}{ Dietary inositol levels ( $\mathrm{mg} \mathrm{kg}^{-1}$ diet) } \\
\hline & 350 & 364 & 458 & 507 & 720 & 1050 \\
\hline Initial weight (g) & $5.51 \pm 0.11$ & $5.54 \pm 0.05$ & $5.52 \pm 0.13$ & $5.53 \pm 0.07$ & $5.47 \pm 0.03$ & $5.51 \pm 0.06$ \\
\hline Final weight $(\mathrm{g})$ & $35.77 \pm 2.42^{\mathrm{a}}$ & $36.29 \pm 3.97^{\mathrm{a}}$ & $36.60 \pm 0.49^{\mathrm{a}}$ & $44.11 \pm 2.00^{\mathrm{b}}$ & $35.71 \pm 1.37^{\mathrm{a}}$ & $38.31 \pm 0.98^{\mathrm{a}}$ \\
\hline Weight gain $(\%)$ & $548.60 \pm 35.82^{\mathrm{a}}$ & $555.19 \pm 76.18^{\mathrm{a}}$ & $563.23 \pm 7.62^{\mathrm{a}}$ & $698.21 \pm 39.39^{\mathrm{b}}$ & $552.96 \pm 22.39^{\mathrm{a}}$ & $595.58 \pm 10.93^{\mathrm{a}}$ \\
\hline Survival (\%) & $88.89 \pm 8.39$ & $90.00 \pm 6.67$ & $90.00 \pm 3.33$ & $87.78 \pm 6.94$ & $88.89 \pm 1.92$ & $90.00 \pm 0.00$ \\
\hline FCR & $1.04 \pm 0.09^{\mathrm{ab}}$ & $1.03 \pm 0.05^{\mathrm{ab}}$ & $1.08 \pm 0.01^{\mathrm{b}}$ & $0.98 \pm 0.01^{\mathrm{a}}$ & $1.03 \pm 0.04^{\mathrm{ab}}$ & $0.96 \pm 0.00^{\mathrm{a}}$ \\
\hline HIS & $2.03 \pm 0.10$ & $2.22 \pm 0.12$ & $2.21 \pm 0.13$ & $2.29 \pm 0.11$ & $2.09 \pm 0.14$ & $2.19 \pm 0.13$ \\
\hline VIS & $9.66 \pm 0.08^{\mathrm{a}}$ & $10.23 \pm 0.1^{\mathrm{b}}$ & $10.43 \pm 0.19^{\mathrm{bc}}$ & $10.08 \pm 0.19^{\mathrm{b}}$ & $10.24 \pm 0.25^{\mathrm{b}}$ & $10.54 \pm 0.27^{\mathrm{c}}$ \\
\hline
\end{tabular}

${ }^{1}$ : Values in the same row with different superscripts are significantly different $(\mathrm{p}<0.05)$. Data are expressed as mean values \pm SD $(\mathrm{n}=3) ;{ }^{2}$ : Weight gain $=100 \times($ final body weight -initial body weight $) /($ initial body weight $){ }^{3}:$ Feed Conversion Ratio $($ FCR $)=$ Weight gain $(\mathrm{g})$ dry $^{-1}$ feed $(\mathrm{g}) ;{ }^{4}$ : Hepatosomatic index (HIS) $=100 \times$ liver weight $/$ body weight $;{ }^{5}$ : Viscerasomatic index (VSI) $=100 \times$ viscera weight/body weight

Table 3: Whole body composition of Lates calcarifer fed diets containing graded levels of inositol Dietary inositol levels $\left(\mathrm{mg} \mathrm{kg}^{-1}\right.$ diet)

\begin{tabular}{|c|c|c|c|c|c|c|}
\hline$\underline{\text { Parameters }}$ & 350 & 364 & 458 & 507 & 720 & 1050 \\
\hline Moisture & $71.59 \pm 0.84$ & $70.50 \pm 0.55$ & $71.61 \pm 0.49$ & $71.24 \pm 0.88$ & $70.46 \pm 0.89$ & $70.87 \pm 0.29$ \\
\hline Crude protein & $17.40 \pm 0.47$ & $17.55 \pm 0.14$ & $17.52 \pm 0.07$ & $17.41 \pm 0.00$ & $17.59 \pm 0.10$ & $17.46 \pm 0.12$ \\
\hline Crude lipid & $6.74 \pm 0.11$ & $7.27 \pm 0.26$ & $6.68 \pm 0.24$ & $7.08 \pm 0.51$ & $7.28 \pm 0.41$ & $6.93 \pm 0.24$ \\
\hline
\end{tabular}

Values in the same row with different superscripts are significantly different $(\mathrm{p}<0.05)$. Data are expressed as mean values \pm SD $(n=3)$

Table 4: Effect of on serum biochemical parameters of Lates calcarifer fed diets containing graded levels of inositol Dietary inositol levels $\left(\mathrm{mg} \mathrm{kg}^{-1}\right.$ diet $)$

\begin{tabular}{lllcccc} 
Parameters & 350 & 364 & 458 & 507 & 720 & 1050 \\
\hline TP $\left(\mathrm{g} \mathrm{L}^{-1}\right)$ & $48.00 \pm 1.74 \mathrm{a}$ & $49.82 \pm 1.06 \mathrm{ab}$ & $52.26 \pm 2.53 \mathrm{~b}$ & $55.32 \pm 0.22 \mathrm{c}$ & $52.09 \pm 0.67 \mathrm{~b}$ & $48.22 \pm 0.94 \mathrm{a}$ \\
$\mathrm{BUN}\left(\mathrm{mmol} \mathrm{L}^{-1}\right)$ & $3.80 \pm 0.10^{\mathrm{bc}}$ & $3.83 \pm 0.81^{\mathrm{bc}}$ & $2.60 \pm 0.50^{\mathrm{a}}$ & $3.55 \pm 0.15^{\mathrm{bc}}$ & $3.20 \pm 0.10^{\mathrm{ab}}$ & $4.30 \pm 0.60^{\mathrm{c}}$ \\
$\mathrm{TC}\left(\mathrm{mmol} \mathrm{L}^{-1}\right)$ & $6.76 \pm 0.17^{\mathrm{a}}$ & $6.66 \pm 0.28^{\mathrm{a}}$ & $6.61 \pm 0.48^{\mathrm{a}}$ & $7.76 \pm 0.34^{\mathrm{c}}$ & $7.56 \pm 0.37^{\mathrm{bc}}$ & $7.07 \pm 0.27^{\mathrm{ab}}$ \\
TG $\left(\mathrm{mmol} \mathrm{L}^{-1}\right)$ & $1.96 \pm 0.13^{\mathrm{ab}}$ & $1.59 \pm 0.30^{\mathrm{a}}$ & $1.88 \pm 0.36^{\mathrm{ab}}$ & $2.02 \pm 0.18^{\mathrm{ab}}$ & $2.12 \pm 0.32^{\text {ab }}$ & $2.24 \pm 0.42^{\mathrm{b}}$ \\
\hline
\end{tabular}

Values in the same row with different superscripts are significantly different $(\mathrm{p}<0.05)$. Data are expressed as mean values \pm SD $(n=3)$. TP: Total Protein; BUN: Blood Urea Nitrogen; TC: Total Cholesterol; TG: Triacylglycerol 


\section{DISCUSSION}

The importance of dietary inositol for normal growth of juvenile Lates calcarifer maybe demonstrated in the present study. Although dietary inositol did not significantly affect survival $(p>0.05)$, weight gain was the significantly highest for barramundi fed the diet containing inositol $507 \mathrm{mg} \mathrm{kg}^{-1}$ diet among all the groups $(\mathrm{p}<0.05)$. Glencross (2006) reviewed that no differences in growth, feed conversion or survival were observed when barramundi were fed practical diets added inositol. On the other hand, inositol was required for its normal growth using semipurified diets. Weight gain increased for fish fed dietary inositol up to the requirement level. The optimal dietary inositol requirement for the maximum growth of juvenile Jian carp (Cyprinus carpio) was estimated to be $518.0 \mathrm{mg} \mathrm{kg}^{-1}$ diet (Jiang et al., 2009); juvenile tilapia (Oreochromis niloticus $\times$ Oreochromis aureus) required $400 \mathrm{mg} \mathrm{kg}^{-1}$ diet (Shiau and $\mathrm{Su}, 2005$ ); juvenile flounder Paralichthys olivaceus required 800-1200 mg $\mathrm{kg}^{-1}$ diet (Li et al., 2001) and Lateclabrax japonicus reqired $500 \mathrm{mg} \mathrm{kg}^{-1}$ diet (Zhong and Zhang, 2001); however, the suitable requirement for dietary inositol of growing grass carp (Ctrnopharyngodon idella) was approximately $166-214 \mathrm{mg} \mathrm{kg}^{-1}$ diet (Wen et al., 2007). Waagbo et al. (1998) reported that no real effect of dietary inositol supplementation on growth and mortality in Atlantic salmon (Salmo salar) feeding practical diets. Moreover, juveniles Nile tilapia (Oreochromis niloticus) (Peres et al., 2004) and sunshine bass (Morone chrysops $\bigcirc \times$ Morone saxatilis ${ }^{\Uparrow}$ ) (Deng et al., 2002) fed puried diets did not require an exogenous source of inositol for normal growth and feed utilization. Dietary inositol did not significantly affect survival ( $\mathrm{p}>0.05)$. This maybe practical diet contain sufficient levels of inositol to meet various metabolic needs of fish because this vitamin is widely distributed in common feed ingredients (Peres et al., 2004).

Hepatosomatic weight were higher at high inositol levels compared with the unsupplemented diet maybe due to inositol increased the promotion of liver development (Jiang et al., 2009). In the present study, the results showed that HSI of barramundi was not affected by dietary levels of inositol. This result demonstrated that high inositol levels had no potential to affect the health of fish. It was also found that dietary inositol did not affect HSI of in Atlantic salmon (Waagbo et al., 1998), sunshine bass (Deng et al., 2002) and Nile tilapia (Peres et al., 2004).

The significantly higher accumulation of lipid in liver and muscle of fish could be an indication of inositol deficiency (Peres et al., 2004). In the present study, no significant difference was found in the moisture, crude protein and lipid contents of the fish whole body. This is also consistent with studies on Atlantic salmon (Waagbo et al., 1998), grass carp (Wen et al., 2007) and Kuruma shrimp (Marsupenaeus japonicus) (Michael and Koshio, 2008). However, in Jian carp (Jiang et al., 2009), whole body moisture was not affected by inositol levels ( $p>0.05)$, but body protein increased significantly with increasing dietary inositol levels up to $384.2 \mathrm{mg} \mathrm{kg}^{-1}$ diet $(\mathrm{p}<0.05)$ and body fat was the highest for fish fed diets containing 838.8 and $990.3 \mathrm{mg} \mathrm{kg}^{-1}$ diet and the lowest for fish fed the unsupplemented diet $(\mathrm{p}<0.05)$.

Good state of health for fish is the basic precondition for successful fish culture. Monitoring the physiological state of fish has become an integral part of the routine examination of fish health (Rehulka, 2000). Apparently any adverse effects were not found on the state of the fish health in this study. However, differences were observed in serum parameters of cultured barramundi among dietary groups. Dietary herbs (Lu et al., 2009) and B. licheniformis (Yuan et al., 2009) could change some blood hematological and blood biochemical indices of the fish. Serum TP levels can be used as a diagnostic tool and a valuable test for evaluating the general physiological state in fish (Pedro et al., 2005). In the present study, TP increased with increasing dietary inositol levels up to $507 \mathrm{mg} \mathrm{kg}^{-1}$ diet $(\mathrm{p}<0.05)$. Significantly low levels of total plasma protein were reported for some infected fish (Benli and Yildiz, 2004; Yildiz and Aydin, 2006; Rehulka and Minarik, 2007); meanwhile, clinical chemistry analyses in blood plasma indicated the decreased levels of total protein (Rehulka and Minarik, 2007). The significantly lowest Blood Urea Nitrogen (BUN) was found in the fish fed dietary inositol $458 \mathrm{mg} \mathrm{kg}^{-1}$ diet among all the groups except for the $720 \mathrm{mg} \mathrm{kg}^{-1}$ diet. The increase of BUN may reflect kidney dysfunction (Liu et al., 2007) and its increased levels generally signal a higher rate of conversion of nitrogen compounds (Rehulka and Minarik, 2003). The TC of fish fed dietary inositol $507-1050 \mathrm{mg} \mathrm{kg}^{-1}$ diet was higher than those of the fish fed dietary inositol $350-458 \mathrm{mg} \mathrm{kg}^{-1}$ diet, but no significant difference was observed ( $>0.05$ ). In grass carp (Wen et al., 2007), TC was significantly lowest for fish fed the unsupplemented diet $(\mathrm{p}<0.05)$. However, the total protein and cholesterol concentrations in plasma were not significantly affected by dietary inositol (Waagbo et al., 1998). TG increased with increasing dietary inositol levels up to 507-720 $\mathrm{mg} \mathrm{kg}^{-1}$ diet $(\mathrm{p}<0.05)$ in this study. This result did not agree with Waagbo et al. (1998) for Atlantic salmon 
and Wen et al. (2007) for Ctrnopharyngodon idella, which plasma TG was negatively correlated to dietary inositol supplementation.

\section{CONCLUSION}

Results of the present investigation demonstrate significant improvement of growth and feed utilization of juvenile barramundi can be achieved by inositol supplementation at $507 \mathrm{mg} \mathrm{kg}^{-1}$ diet.

\section{REFERENCES}

AOAC., 1984. Official Methods of Analysis. 14th Edn., Association of Official Analytical Chemists, Arlington, VA., pp: 114.

Ashizawa, N., M. Yoshida and T. Aotsuka, 2000. An enzymatic assay for myo-inositol in tissue samples. J. Biochem. Biophys. Methods, 44: 89-94. DOI: 10.1016/S0165-022X(00)00069-5

Benli, A.C.K. and H.Y. Yildiz, 2004. Blood parameters in Nile tilapia (Oreochromis niloticus L.) spontaneously infected with Edwardsiella tarda. Aquac. Res., 35: 1388-1390. DOI: 10.1111/j.13652109.2004.01158.x

Deng, D.F., G.I. Hemre and R.P. Wilson, 2002. Juvenile sunshine bass (Morone chrysops $q \times$ Morone saxatilis ${ }^{\wedge}$ ) do not require dietary myoinositol. Aquaculture, 213: 387-393. DOI: 10.1016/S0044-8486(02)00119-9

Glencross, B., 2006. The nutritional management of barramundi, Lates calcarifer-a review. Aquac. Nutr., 12: 291-309. DOI: 10.1111/j.13652095.2006.00410.x

Harpaz, S., Y. Hakim, T. Slosman and O.T. Eroldogan, 2005. Effects of adding salt to the diet of Asian sea bass Lates calcarifer reared in fresh or salt water recirculating tanks, on growth and brush border enzyme activity. Aquaculture, 248: 315-324. DOI: 10.1016/j.aquaculture.2005.03.007

Jiang, W.D., L. Feng, Y. Liu, J. Jiang and X.Q. Zhou, 2009. Growth, digestive capacity and intestinal microflora of juvenile Jian carp (Cyprinus carpio var. Jian) fed graded levels of dietary inositol. Aquac. Res., 40: 955-962. DOI: 10.1111/j.13652109.2009.02191.X

Katersky, R.S. and C.G. Carter, 2009. Growth and protein synthesis of barramundi, Lates calcarifer, fed lupin as a partial protein replacement. Comparit. Biochem. Physiol.-Part A: Mol. Integrat. Physiol., 152: 513-517. DOI: 10.1016/j.cbpa.2008.12.017
Li, A.J., D.B. Zhang, W.Q. Wei and X.J. Zhang, 2001. A study on the nutritional requirement for juvenile flounder Paralichthys olivaceus. J. Zhejiang Ocean Univ. (Nat. Sci.), 20: 6-10. http://d.wanfangdata.com.cn/Periodical_zjhyxyxbzr2001z1002.aspx

Liu, S.M., X.N. Zang, B. Liu, X.C. Zhang and A.K. Kiu et al., 2007. Effect of growth hormone transgenic Synechocystis on growth, feed efficiency, muscle composition, haematology and histology of turbot (Scophthalmus maximus L.). Aquac. Res., 38: 1283-1292. DOI: 10.1111/j.1365-2109.2007.01796.x

Lu, X., H.Z. Lin, Z.J. Li, F.H. Yuan and Q.B. Yang, 2009. Effect of dietary Chinese herbal medicines on hematological and blood biochemical indices in cultured seabass Lates calarifer. J. Dalian Fish. Univ., 24: 279-282. http://en.cnki.com.cn/Article_en/CJFDTOTALDLSC200903019.htm

Michael, F.R. and S. Koshio, 2008. Biochemical studies on the interactive effects of dietary choline and inositol in juvenile Kuruma shrimp, Marsupenaeus japonicus Bate. Aquaculture, 285: 179-183. DOI: 10.1016/j.aquaculture.2008.08.006

Pedro, N., A.I. Guijarro, M.A. López-Patino, R. MartinezAlvarez and M.J. Delgado, 2005. Daily and seasonal variations in haematological and blood biochemical parameters in the tench, Tinca tinca Linnaeus, 1758. Aquac. Res., 36: 1185-1196. DOI: 10.1111/j.1365-2109.2005.01338.x

Peres, H., C. Lim and P.K. Klesius, 2004. Growth, chemical composition and resistance to Streptococus iniae challenge of juvenile Nile tilapia (Oreochromis niloticus) fed graded levels of dietary inositol. Aquaculture, 235: 423-432. DOI: 10.1016/j.aquaculture.2003.09.021

Rehulka, J., 2000. Influence of astaxanthin on growth rate, condition and some blood indices of rainbow trout, Oncorhynchus mykiss. Aquaculture, 190: 27-47. DOI: $10.1016 / \mathrm{S} 0044-8486(00) 00383-5$

Rehulka, J. and B. Minarik, 2007. Blood parameters in brook trout Salvelinus fontinalis (Mitchill, 1815), affected by columnaris disease. Aquac. Res., 38: 1182-1197. DOI: $10.1111 / \mathrm{j} .1365-$ 2109.2007.01786.x

Rehulka, J. and B. Minarik, 2003. Effect of lecithin on the haematological and condition indices of the rainbow trout Oncorhynchus mykiss (Walbaum). Aquac. Res., 34: 617-627. DOI: 10.1046/j.13652109.2003.00855.x 
Shiau, S.Y. and S.L. Su, 2005. Juvenile tilapia (Oreochromis niloticus $\times$ Oreochromis aureus) requires dietary myo-inositol for maximal growth. Aquaculture, 243: 273-277. DOI: 10.1016/j.aquaculture.2004.10.002

Tantikittia, C., W. Sangpongb and S. Chiavareesajjaa, 2005. Effects of defatted soybean protein levels on growth performance and nitrogen and phosphorus excretion in Asian seabass (Lates calcarifer). Aquaculture, 248: 41-50. DOI: 10.1016/j.aquaculture.2005.04.027

Waagbo, R., K. Sandnes and O. Lie, 1998. Effects of inositol supplementation on growth, chemical composition and blood chemistry in Atlantic salmon. Salmo salar L., fry. Aquac. Nutr., 4: 53-59. DOI: 10.1046/j.1365-2095.1998.00043.x

Wen, H., Z.Y. Zhao, M. Jiang, A.L. Liu and F. Wu et al., 2007. Dietary myo-inositol requirement for grass carp, Ctrnopharyngodon idella fingerling. J. Fish. Sci. China, 14: 794-800. http://en.cnki.com.cn/Article_en/CJFDTOTALZSCK200705013.htm

Williams, K.C., C.G. Barlow, L. Rodgers and C. Agcopra, 2006. Dietary composition manipulation to enhance the performance of juvenile barramundi (Lates calcarifer Bloch) reared in cool water. Aquac. Res., 37: 914-927. DOI: 10.1111/j.13652109.2006.01513.x
Yildiz, H. and S. Aydin, 2006. Pathological effects of Arcobacter cryaerophilus Infection in rainbow trout (Oncorhynchus mykiss Walbaum). Acta Veterinaria Hungarica, 54: 191-199. DOI: 10.1556/AVet.54.2006.2.6

Yuan, F.H., H.Z. Lin, Z.J. Li, X. Lu and Q.B. Yang, 2009. Effects of dietary Bacillus licheniformis on blood physiological-biochemical indices in cultured Lates calarifer. South China Fish. Sci., 5: 45-50.

http://www.cqvip.com/qk/60642A/200902/299412 97.html

Zhong, W.R. and X.H. Zhang, 2001. Studies on the requirements of Lateclabrax japonicus for vitamins at various growth stages. J. Zhejiang Ocean Univ. (Nat. Sci.), 20: 99-102. http://www.cqvip.com/qk/97875A/200903/ 